\title{
UCR RADIOCARBON DATES II
}

\author{
R E TAYLOR \\ Department of Anthropology, \\ Center for Social and Behavioral Science Research, \\ Institute of Geophysics and Planetary Physics, \\ University of California, Riverside, California 92502
}

UCR I (R, 1974, v 16, p 395-401) previously reported measurements carried out jointly by the UCR and UCLA radiocarbon laboratories between November 1972 and September 1973 and interlaboratory check samples used to calibrate the UCR $1.7 \mathrm{~L}$ counter. This list reports the measurements of the UCR laboratory from September 1973 to August 1974.

Samples were subjected to accepted $\mathrm{HCl}, \mathrm{NaOH}$ or other special chemical pretreatments depending on specific conditions to exclude contamination. All bone samples were measured using the collagen method of Berger et al (1964). Samples are combusted in a stream of oxygen and argon or acidified with $2 \mathrm{~N} \mathrm{HCl}$ and the resultant $\mathrm{CO}_{2}$ is passed through 2 washing bottles containing . $1 \mathrm{~N} \mathrm{AgNO}_{3}$ solutions, a $\mathrm{CuO}$ furnace maintained at $800^{\circ} \mathrm{C}$, 2 solutions of ca $100 \mathrm{gm}$ of $\mathrm{K}_{2} \mathrm{Cr}_{2} \mathrm{O}_{2}$ dissolved in $\mathrm{H}_{2} \mathrm{SO}_{4}$, 2 additional .1N $\mathrm{AgNO}_{3}$ solutions, and is collected in liquid $\mathrm{N}_{2}$ traps. After combustion or evolution of the $\mathrm{CO}_{2}$ is completed, the sample is isolated in the vacuum system and the remaining excess $\mathrm{O}_{2}$ and other noncondensable gases are pumped off. The sample is then expanded into a separate 10L system containing a Cu furnace maintained at $400^{\circ} \mathrm{C}$. A fan unit in the system circulates the $\mathrm{CO}_{2}$ continuously through the $\mathrm{Cu}$ for at least a $10-\mathrm{hr}$ period. Between each sample, the $\mathrm{Cu}$ is reduced by the introduction of $\mathrm{H}_{2}$. Following circulation through the $\mathrm{Cu}$ furnace, the $\mathrm{CO}_{2}$ is again collected in a liquid $\mathrm{N}_{2}$ trap and pumped with a mercury-diffusion pump until a vacuum of $10^{-3} \mathrm{~mm} \mathrm{Hg}$ or less is attained. The sample is then stored in stainless steel pressure bottles to allow radon to decay.

Samples are introduced into a $1.7 \mathrm{~L}$ counter at $760 \mathrm{~mm}$ pressure normalized to $20^{\circ} \mathrm{C}$. Concentration of electro-negative impurities in the samples gases is monitored by noting the ratio between meson events falling into 2 energy channels as a function of change in the high voltage. A 2-channel discriminator unit has been set so that, at given voltage with the anti-coincidence system deactivated, counting rates in the 2 channels are approximately equal when the purity of the sample gas is acceptable for counting purposes. If the voltage is $>10$ volts above the standard voltage setting, the sample is recycled through the $\mathrm{Cu}$ furnace for an additional period.

Background $\mathrm{CO}_{2}$ is obtained from the acidification of marble of Pennsylvanian age. Calculated radiocarbon ages are based on the $5568 \mathrm{yr}$ half-life; the standard for the contemporary biosphere is .95 NBS oxalic acid and $\mathrm{AD} 1950$ constitutes the zero reference year. The measured ${ }^{13} \mathrm{C} /$ ${ }^{12} \mathrm{C}$ ratio of the oxalic acid standard gas is -19.74 per mil relative to PDB. The interlaboratory check sample results were reported in UCR I. 
ACKNOWLEDGMENTS

The author wishes to express his gratitude to W F Libby and Rainer Berger for their continuing assistance. The dedicated laboratory work of Marvis Kelly, Peter Slota, and Stanley Sheldon is also very much appreciated. Support from the UCR Intramural Research Fund is gratefully acknowledged.

\section{SAMPLE DESCRIPTIONS}

\section{ARCHAEOLOGIC SAMPLES}

\section{A. California}

\section{Myoma Dunes series}

Samples from coprolite beds exposed in sand dunes adjacent to shoreline of former Lake Cahuilla (LeConte), Riverside Co, Calif (33 $45^{\prime} \mathrm{N}$, $116^{\circ} 12^{\prime} \mathrm{W}$ ) by deflation. Coll 1973 and subm by $\mathrm{P} J$ Wilke, Dept Anthropol, Univ California, Riverside.

\section{UCR-124. Coprolite Bed D}

$365 \pm 140$

Human coprolite from shallow latrine. Coprolites and decomposing fragments thereof contained seeds of Cucurbita pepo id by $\mathrm{T}$ Whitaker, US Dept Agric, La Jolla, California. Comments (PJW): significance of cucurbit seeds at this date awaits completion of coprolite analysis, which is in progress. (RET): interlab check sample, UCLA-1889: $420 \pm 80$.

\section{UCR-125. Coprolite Bed B}

Human coprolite from $15 \mathrm{~cm}$ below surface of deposit. Comments $(\mathrm{PJW})$ : date suggests recent deposit. Componential analysis of coprolites is in progress. (RET): interlab check sample, UCLA-1887: <100 yr.

\section{UCR-152. Coprolite Bed A-terrestrial fraction}

$240 \pm 150$

Seed coats of Mesquite (Prosopis juliflora) screened from upper $10 \mathrm{~cm}$ of decomposing bed of coprolites atop shoreline dune. Comment (PJW): sample dates terrestrial plant remains consumed by man.

$$
235 \pm 150
$$

\section{UCR-153. Coprolite Bed A-aquatic fraction AD 1715}

Seeds of Scirpus acutus and $S$ validus, id by Norah van Kleeck, California Dept Agric, Sacramento, screened from residue of decomposing coprolites. Provenience same as UCR-152. Comment (PJW): same apparent age as terrestrial fraction from same deposit.

\section{UCR-163. Structure}

Charcoal, probably Mesquite (Prosopis juliflora) from a beam of burned pole and brush structure from the deflating surface of Myoma Dunes, Area A. Comment (RET): interlaboratory check sample, UCLA1918: $100 \pm 60, \mathrm{AD} 1850$. 
General Comment (PJW): coprolites from Bed A include abundant remains of aquatic plants and animals. Dates on coprolite constituents suggest a late stand of Lake Cahuilla, which was not anticipated. The number and duration of late stands of Lake Cahuilla has not yet been determined.

\section{UCR-120/UCLA-1868. Tahquitz Canyon}

Charcoal from hearth (Feature A) in Unit E, Exposure 3, Loc TC$27 \mathrm{~N}$, alluvial fan of Tahquitz Canyon ( $33^{\circ} 50^{\prime} \mathrm{N}, 116^{\circ} 32^{\prime} \mathrm{W}$ ) Coachella Valley, California. Coll 1972 by G Jefferson, subm by P J Wilke, Dept Anthropol, Univ California, Riverside. Comment (PJW): date indicates occupation of site into late prehistoric or historic time.

\section{UCR-212. Simomo site}

Marine shell (Chicone undatella simillima [Sowerby], Argopecten circularis aequisulcatus [Carpenter], and Euspira lewisi [Gould]) from 350 to $365 \mathrm{~cm}$ at Simomo site (4-Ven-26), Ventura Co, California $\left(35^{\circ} 10^{\prime} \mathrm{N}\right.$, $119^{\circ} 10^{\prime} \mathrm{E}$ ). Coll 1959 by C Rozaire, L A Co Mus Natl Hist. Subm by R E Taylor.

\section{Santa Cruz Island series}

A series of test excavations were conducted by Univ California, Santa Barbara on Santa Cruz, one of the channel islands off the coast of Southern California. Radiocarbon dates of this series are being used for chronology of changes in exploitation of marine resources by prehistoric inhabitants of Santa Cruz I. Theoretically, as population density increased, kelp fish and eventually schooling fish were added to intertidal food resources in the aboriginal diet. Dates correlate with screened column samples from which subsistence remains are being extracted for analysis. Excavations are supported by a Natl Sci Foundation Grant (GA-36573) to A Spaulding and M A Glassow. Samples subm by M A Glassow, Dept Anthropol, Univ California, Santa Barbara.

\section{UCR-130. Christi Beach, 185 to $195 \mathrm{~cm}$}

$1685 \pm 100$

Wood charcoal from 185 to $195 \mathrm{~cm}$ in Column 1 at UCSB site SCrI$236\left(34^{\circ} 1^{\prime} \mathrm{N}, 119^{\circ} 52^{\prime} \mathrm{W}\right)$. Coll 1973 by M A Glassow.

\section{UCR-131. Christi Beach, 238 to $248 \mathrm{~cm}$}

$4435 \pm 100$

Marine shell (Haliotis sp) from 238 to $248 \mathrm{~cm}$ in Column 1. Coll 1973 by M A Glassow.

\section{UCR-132. Christi Beach, 205 to $220 \mathrm{~cm}$}

Wood charcoal from burnt timber from 205 to $220 \mathrm{~cm}$ in Column 2. Coll 1973 by M A Glassow. 
UCR-156. Prisoner's Harbor, 185 to $200 \mathrm{~cm}$

$960 \pm 150$

Charcoal from Level A., 185 to $200 \mathrm{~cm}$ above main datum at UCSB site SCrI-240 ( $\left.34^{\circ} 01^{\prime} \mathrm{N}, 119^{\circ} 40^{\prime} \mathrm{W}\right)$. Coll 1973 by S P Horne.

UCR-157. Prisoner's Harbor, 115 to $125 \mathrm{~cm}$

$1650 \pm 150$

Charcoal from Level E, 115 to $125 \mathrm{~cm}$ above main datum. Coll 1973 by S P Horne.

UCR-158. Prisoner's Harbor, 33 to $36 \mathrm{~cm}$

$1735 \pm 150$

Charcoal from Level 0, 33 to $36 \mathrm{~cm}$ below main datum. Coll 1973 by S P Horne.

UCR-159. Prisoner's Harbor, 133 to $155 \mathrm{~cm}$

$1795 \pm 150$

AD 155

Charcoal from Level X, 133 to $135 \mathrm{~cm}$ below main datum. Coll 1973 by M A Glassow.

UCR-127. Prisoner's Harbor, 0 to $16 \mathrm{~cm}$

$980 \pm 100$

Charcoal from Level L, 0 to $16 \mathrm{~cm}$ above main datum. Coll 1973 by S P Horne. Comment (RET): interlab check sample UCLA-1891: 1160 \pm 80 .

UCR-128. Prisoner's Harbor, 64 to $78 \mathrm{~cm}$

$1015 \pm 100$

Marine shell (Mytilus califorianus) from Level $\mathrm{I}_{1}, 64$ to $78 \mathrm{~cm}$ above main datum. Coll 1973 by S P Horne. Comment (RET): interlab check sample, UCLA-1892: $1170 \pm 80$.

UCR-164. Prisoner's Harbor, 248 to $256 \mathrm{~cm}$

$4430 \pm 150$

2480 вC

Charcoal from Level $\mathrm{HH}, 248$ to $256 \mathrm{~cm}$ below main datum. Coll 1973 by M A Glassow.

UCR-165. Prisoner's Harbor, 193 to $216 \mathrm{~cm}$

$2825 \pm 150$

875 вC

Charcoal from Level DD, 193 to $216 \mathrm{~cm}$ below main datum. Coll 1973 by M A Glassow.

UCR-166. Prisoner's Harbor, 171 to $177 \mathrm{~cm}$

$2290 \pm 125$

340 BC

Charcoal from Level AA, 171 to $177 \mathrm{~cm}$ below datum. Coll 1973 by M A Glassow.

UCR-167. Prisoner's Harbor, 88 to $102 \mathrm{~cm}$

$2190 \pm 150$

240 BC Glassow.

Charcoal from Level S, 88 to $102 \mathrm{~cm}$ below datum. Coll 1973 by M A

General Comment (MG): UCR-130 and -132, from a strata-cut made into a cross sec of midden exposed by seacliff erosion, date intermediate levels 
of SCrI-236 (UCSB designation), and UCR-131 dates lowermost stratum at same site. UCR-127 and -128, -156-159, and -164-167 are derived from a 50 to $50 \mathrm{~cm}$ column sample from a stream-cut cross sec of Site SCrI-240 (UCSB designation). All measurements are from a datum plane $231 \mathrm{~cm}$ below uppermost portion of column. Sequence of samples, from top to bottom, is UCR-156, -157, -128, -127, -158, -167, -159, -166, and -164. The lowermost deposits, which lie below the water table, have not yet been reached. UCR-157 and -159 appear to be anomalous dates in that they are significantly later in time than date directly above, respectively.

\section{Farmington series}

Samples were coll as part of excavations conducted by Univ of California, Davis at the Farmington loc, San Joaquin Co, $\left(37^{\circ} 50^{\prime} \mathrm{N}, 121^{\circ} 10^{\prime}\right.$ W). Samples coll 1973 and subm by B W Hatoff, Dept Anthropol, Univ California, Davis.

UCR-178. Farmington, 90 to $100 \mathrm{~cm}$ $<\mathbf{1 5 0}$

Charcoal from Unit 2-G, 90 to $100 \mathrm{~cm}$ below datum.

Modern

UCR-179. Farmington, 110 to $120 \mathrm{~cm}$

$250 \pm 150$

Charcoal from Unit 2-C, 100 to $110 \mathrm{~cm}$ below datum.

UCR-180. Farmington, 110 to $20 \mathrm{~cm}$

Charcoal from Unit 2-C, 110 to $120 \mathrm{~cm}$ below datum.

Modern

General Comment (BWH): modern dates from the Farmington rock shelter do not correlate with dates obtained from nearby Farmington complex locations (Heizer, 1964; Treganza, 1952, 1955). Based on internal agreement and disparate dates for rock shelter and Farmington gravels, 2 separate archaeologic entities are involved; therefore UCR-178, -179, -180 dates should not be considered erroneous.

\section{Northern and Central California archaeologic series}

The Cultural Resources Sec, California State Dept Parks \& Recreation studied several archaeologic localities in Central and Northern California in the last decade. Significance of these results will be discussed elsewhere. All samples subm by F A Riddell, Dept Parks \& Recreation, California.

\section{UCR-137. Commanche, Burial 58}

$3630 \pm 300$ $1680 \mathrm{BC}$

Bone collagen from Burial 58, $150 \mathrm{~cm}$ depth, from Site Ca-Cal-236, Commanche, California $\left(38^{\circ} 13^{\prime} \mathrm{N}, 120^{\circ} 53^{\prime} \mathrm{W}\right)$ in foothills of Central California Sierra range. Coll 1963 by J J Johnson, subm by F A Riddell. Comment (ET): preservative on bone removed by continuous benzene extraction in Sohset extractor. Comment (FAR): sample should date early component at site, attributed to central California Early period, Windmiller pattern. 
UCR-138. Sutter's Fort, Burial 9

$1850 \pm 150$

Human bone collagen (left femur) from Burial 9, 60cm depth, from Site Ca-SAc-34 (38 $34^{\prime}$ N, $121^{\circ} 28^{\prime}$ W) , Sutter's Fort State Historic Park, Sacramento, California. Coll 1959 by W H Olsen and L A Payen. Comment (FAR): sample should date early component at site attributed to Central California Middle period.

UCR-139. Franklin, Burial 19

$3300 \pm 150$

Human bone collagen (right tibia) from Burial 19, an intrusive burial 120 to $156 \mathrm{~cm}$ depth near base of midden deposit at Site Ca-Sac-145 $\left(38^{\circ} 20^{\prime} \mathrm{N}, 121^{\circ} 27^{\prime} \mathrm{W}\right)$ near Franklin in Lower Sacramento Valley, California. Coll 1971 by W E Pritchard. Comment (FAR): sample should date Middle period, Berkeley pattern at site.

UCR-140. Stockton, Burial 25

$2860 \pm 150$

910 BC

Human bone collagen (right femur) from Burial 25, $80 \mathrm{~cm}$ depth, at Site Ca-SJo-112 (38 $\left.01^{\prime} \mathrm{N}, 121^{\circ} 20^{\prime} \mathrm{W}\right)$ near Stockton in San Joaquin Valley, California. Coll 1958 by W H Olsen. Comment (FAR): sample should date to terminal portion of Central California Early period, Windmiller pattern.

\section{UCR-141. Stockton, Burial 34}

$3200 \pm 150$

1250 вC

Human bone collagen (left tibia) from Burial $34,94 \mathrm{~cm}$ depth, at Site Ca-S Jo-112 (38 $\left.01^{\prime} \mathrm{N}, 121^{\circ} 20^{\prime} \mathrm{W}\right)$ near Stockton in N San Joaquin Valley, California. Coll 1958 by W H Olsen. Comment (FAR): sample should date to terminal portion of Central California Early period, Windmiller pattern, but should be older than UCR-140.

\section{UCR-142. Thornton, Burial 1}

$1870 \pm 250$

AD 80

Human bone collagen from Burial 1,10 to $15 \mathrm{~cm}$ depth, at Site CaSJo-145 (38 $\left.14^{\prime} \mathrm{N}, 121^{\circ} 27^{\prime} \mathrm{W}\right)$ near Thornton in San Joaquin Valley, California. Coll by P Schulz. Comment (FAR): should date to Central California Early period, Windmiller pattern. Burial disturbed. Discrepancy with other dates for Windmiller pattern.

\section{UCR-143. Thornton, Burial 2}

$$
900 \pm 250
$$

\section{AD 1050}

Human bone collagen from Burial 2, 20 to $30 \mathrm{~cm}$ depth, at Site CASJo-145 (38 $\left.14^{\prime} \mathrm{N}, 121^{\circ} 27^{\prime} \mathrm{W}\right)$ near Thornton in N San Joaquin Valley, California. Coll 1973 by P Schulz. Comment (FAR): see comments on UCR-142.

\section{UCR-144. Thornton, Burial 3}

$$
2500 \pm 200
$$

550 вC

Human bone collagen from Burial 3, 30 to $40 \mathrm{~cm}$ depth, at Site CaSJo-145 (38 $\left.14^{\prime} \mathrm{N}, 121^{\circ} 27^{\prime} \mathrm{W}\right)$ near Thornton, in N San Joaquin Valley, 
California. Coll 1973 by P Schulz. Comment (FAR): sample should date to Central California Early period.

UCR-145. Verona, Burial 14

$865 \pm 150$

Wood charcoal assoc with Burial 14, $37 \mathrm{~cm}$ depth, at Site Ca-Yol-13 $\left(38^{\circ} 47^{\prime} \mathrm{N}, 121^{\circ} 37^{\prime} \mathrm{W}\right)$ near Verona, Sacramento Valley, California. Coll 1957 by F A Riddell and W H Olsen. Comment (FAR): sample should date upper portion of Early Phase I, Late period cemetery at site.

\section{UCR-146. Verona, Burial 65}

$815 \pm 150$

Wood charcoal assoc with Burial 65, 81 cm depth, at Site Ca-Yol-13 $\left(38^{\circ} 47^{\prime} \mathrm{N}, 121^{\circ} 37^{\prime} \mathrm{W}\right)$ near Verona, Sacramento Valley, California. Coll 1957 by F A Riddell and W H Olsen. Comment (FAR): sample should date early phase of Central California Late period.

\section{UCR-122/UCLA-1797. Lower Willow Creek site AD 100}

$1850 \pm 100$

Bone collagen from human bone from Karlo period, Lower Willow

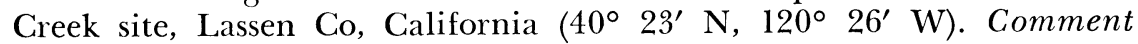
(FAR): sample provides another date for Elko series of projectile points in Great Basin. Obsidian hydration readings were obtained from artifacts from this burial (Riddell, 1975).

\section{UCR-121. Fort Ross, California}

Wood (Sequoia sempervirens) within alluviated stream course within basal blue clay near base of original stream bed from Fort Ross State Historic Park, Sonoma Co, California (38 $31^{\prime}$ N, $123^{\circ} 13^{\prime}$ W). Coll 1973 by R Hatch. Subm by F A Riddell, California Dept Parks \& Recreation. Comment (RET): interlab check sample, UCLA-1870: $>40,000$.

\section{Potter Creek Cave series}

Excavations conducted in Potter Creek Cave $\left(40^{\circ} 47^{\prime} \mathrm{N}\right.$ Lat, $122^{\circ} 17^{\prime}$ W Long), Shasta Co, California, during 1902 and 1903 disclosed tool-like polished bone splinters, a flaked river pebble, and charcoal in apparent assoc with extinct fauna (Sinclair, 1904; Putnam, 1906). This controversial contention (see Heizer, 1964, p 119-120) was restudied with support by Univ California, Davis. Samples will help establish temporal relationship between cultural materials and Pleistocene fossils from cavern. Samples coll 1965 and subm by L A Payen, Dept Anthropol.

\section{UCR-148. Dart shaft}

$1915 \pm 150$

Unid. wooden atlatl dart shaft fragment from cache in Upper Cave. Comment (LAP): sample helps establish hiatus believed to exist between human use of cave and deposition of extinct animal remains. Sample dates 1st autochthonous atlatl reported from N California (Payen, 1970). 


\section{UCR-150. Midden station}

Wood charcoal from superficial midden stratum resting on yellow clay containing Pleistocene faunal remains in 2nd chamber of Upper Cave. Comment (LAP): sample will help establish temporal hiatus between human use of cave and extinct faunal remains.

UCR-151. Dart shaft

$2010 \pm 150$

Unid. wooden atlatl dart shaft fragment from cache in Upper Cave. Comment (LAP): see UCR-148.

\section{UCR-123. Sayles site}

$$
990 \pm 150
$$

Bone collagen from human bone, from pit excavated into sterile alluvium ca $70 \mathrm{~cm}$ below surface of Sayles site, Crowder Canyon, San Bernardino Co, California (34 $\left.19^{\prime} \mathrm{N}, 117^{\circ} 27^{\prime} \mathrm{W}\right)$. Sayles complex was provisional dated by Kowta to between 1000 BC and AD 1000. Coll 1973 and subm by C White, Dept Anthropol, Univ California, Los Angeles.

\section{Fremont Point series}

$$
\text { B. Nevada }
$$

Excavations were made at Fremont Point, Moapa Valley, S E Nevada $\left(36^{\circ} 39^{\prime} \mathrm{N}, 114^{\circ} 35^{\prime} \mathrm{W}\right)$ to determine temporal and cultural relationships between Moapa Valley and Anasazi area of prehistoric SW United States. Coll 1973 and subm by $\mathrm{T}$ Soule, Dept Anthropol, Univ California, Riverside.

\section{UCR-161. Fremont Point, pit house}

$$
\begin{array}{r}
880 \\
\text { AD } 1070
\end{array}
$$

Bone collagen from intrusive child burial in fill of burned pit house $100 \mathrm{~cm}$ deep, assoc with P III ceramic.

\section{UCR-162. Fremont Point, pit house}

$$
1420 \pm 150
$$

Charcoal from wooden beam, $90 \mathrm{~cm}$ in fill of burned pit house.

General Comment (TS): prior to above determinations, no radiocarbon values were available for Moapa Valley at Fremont Point site. Temporal and cultural relationships between Moapa Valley and Anasazi area is indicated from Classic BM III to early P III periods.

\section{UCR-170. Mt Grant, Nevada}

$$
1610 \pm 150
$$$$
\text { AD } 340
$$

Limber pine (Pinus flexilis) from grove of dead trees at $3048 \mathrm{~m}$ on Mt Grant, Nevada $\left(38^{\circ} 20^{\prime} \mathrm{N}, 115^{\circ} 30^{\prime} \mathrm{W}\right)$. Date determines time of favorable conditions for tree growth on $\mathrm{W}$ slope of $\mathrm{mt}$ range. Coll 1974 by $\mathrm{M}$ Lepper, Dept Botany, Univ California, Davis. Subm by M G Barbour, Dept Botany, Univ California, Davis. 
UCR-129. Quintero Ixtlahaucan, Colima

Charcoal assoc with Capacha complex from looted burial context from Quintero Ixtlahuacan, Colima, W Mexico $\left(18^{\circ} 45^{\prime} \mathrm{N}, 103^{\circ} 40^{\prime} \mathrm{W}\right)$. Coll 1973 and subm by I Kelly, Tepepan, Mexico. Comment (RET): interlab check sample, UCLA-1888: $190 \pm 60$. Obviously, samples does not relate to Capacha complex, but derives from period of burial looting.

$$
\text { C. Egypt }
$$

\section{UCR-126. Sesostris III funerary boat}

$3750 \pm 110$

$1800 \mathrm{BC}$

Wood from deck board from funerary boat of Sesostris III obtained in 1948 from Chicago Mus Natl Hist at request of W F Libby. Comment (RET): interlab check sample, UCLA-900: $3640 \pm 80$ (Berger et al, 1965), C-81: $3621 \pm 180$ (Libby, 1955).

\section{PALEOENVIRONMENTAL SAMPLES}

\section{Black Butte series}

Creosote (Larrea divaricate) wood samples from Black Butte, Los Angeles Co $\left(34^{\circ} 33^{\prime} \mathrm{N}, 117^{\circ} 42^{\prime} \mathrm{W}\right)$ were measured to determine pattern and rate of vegetative reproduction for this species, in situations in which living creosote bushes cluster in a ring shape around dead creosote remnants. All samples coll 1974 by F Vasek and H Johnson. Subm by F Vasek, Dept Biol, Univ California, Riverside.

\section{UCR-171. Black Butte B-1}

$295 \pm 150$

Wood, $8 \mathrm{~cm}$ under surface, $40 \mathrm{~cm}$ from nearest living creosote material.

\section{UCR-172. Black Butte B-2}

$$
\mathbf{2 8 0} \pm \mathbf{1 5 0}
$$

Wood from possible root in sand mound, 30 to $40 \mathrm{~cm}$ from surface, 100 to $130 \mathrm{~cm}$ from nearest living creosote material.

\section{UCR-173. Black Butte B-4}

Wood from possible root in sand mound, ca $30 \mathrm{~cm}$ from surface, $110 \mathrm{~cm}$ from nearest living creosote material. UCR-173 and -176 taken $70 \mathrm{~cm}$ apart on same piece of wood.

\section{UCR-174. Black Butte B-5}

$640 \pm 150$

Wood from near surface of sand mound, $100 \mathrm{~cm}$ from nearest living creosote material. UCR-174 and -175 taken 3 to $4 \mathrm{~cm}$ apart on same piece of wood.

\section{UCR-175. Black Butte B-8}

Wood from near surface of sand mound, $100 \mathrm{~cm}$ from nearest living creosote material. See description of UCR-174. Comment (FV): previous 
estimate of age of remnant creosote was ca $100 \mathrm{yr}$. Based on these samples, such material can be as old as ca $700 \mathrm{yr}$. Rates of formation calculated from these samples, suggest that some other remnant structure may be as old as 6000 to $7000 \mathrm{yr}$. Such an age, if supported, would greatly aid the study of population dynamics and age structure within populations of this species of creosote.

UCR-154. Sacramento Mts

$585 \pm 150$

Wood from dead center of bush coll $100 \mathrm{~m}$ N of Hwy I-15 in Sacramento Mts, California. Coll 1974 and subm by F Vasek, Dept Biol, Univ California, Riverside.

UCR-177. Lloyd's Meadow

$\begin{aligned} 520 & \pm 100 \\ \text { AD } 1430 & \end{aligned}$

Manzanita wood (Arctostaphylos patula) from Lloyd's Meadow, Tulare Co, California $\left(35^{\circ} 55^{\prime} \mathrm{N}, 118^{\circ} 30^{\prime} \mathrm{W}\right)$ from granitic bedrock at $1830 \mathrm{~m}$ alt, ca $4 \mathrm{~m}$ from nearest living bush.

\section{Lucerne Valley, California Paleoclimatic series}

A series of middens of wood rat (Neotoma) were excavated to provide paleoclimatic data for late Pleistocene and Holocene periods in $\mathrm{W}$ Mohave Desert of interior S California. Samples were subm by T Jackson King, Jr and R E Taylor, Dept Anthropol, Univ California, Riverside.

\section{UCR-133. Lucerne Valley Midden \#15}

$1610 \pm 150$

Wood twigs from bottom level of concreted wood rat midden under overhang on $S$ facing granitic outcropping on Negro Butte $\left(34^{\circ} 29^{\prime} \mathrm{N}\right.$, $116^{\circ} 46^{\prime} \mathrm{E}$ ), Lucerne Valley, California at alt ca $1005 \mathrm{~m}$. Coll 1974 by $\mathrm{T}$ Jackson King, Jr.

\section{UCR-134. Sunset Cove Midden}

$5880 \pm 250$ 3930 BC

Wood twigs and Opuntia basilaria cactus pad from bottom level of concreted wood rat midden within cave on $\mathrm{N}$ facing slope on Granite Mt, Lucerne Valley, California at alt ca $963 \mathrm{~m}\left(34^{\circ} 27^{\prime} \mathrm{N}, 117^{\circ} 00^{\prime} \mathrm{E}\right)$. Coll 1973 by T Jackson King, Jr.

\section{UCR-135. Lucerne Peak Midden}

$5800 \pm 250$

Single twig from bottom level of concreted wood rat midden located within vertical crevice betwen 2 rockfaces on $\mathrm{E}$ facing slope near Lucerne Peak, Lucerne Valley, California $\left(34^{\circ} 33^{\prime} \mathrm{N}, 116^{\circ} 59^{\prime} \mathrm{E}\right)$ at alt ca $1097 \mathrm{~m}$. Coll 1974 by T Jackson King, Jr.

\section{UCR-181. Lucerne Valley Midden \#13}

$12,100 \pm 400$

Juniper (Juniperus osteosperma) seeds and twigs from level A, ca $1 \mathrm{~m}$ deep into Lucerne Valley GM-5 midden $\left(34^{\circ} 29^{\prime} \mathrm{N}, 116^{\circ} 46^{\prime} \mathrm{W}\right)$. Coll 1974 by T Jackson King, Jr and R E Taylor. 


\section{UCR-149. Ord Mountain Midden}

Juniper (Juniperus osteosperma) seeds from Level 1 of concreted wood rat midden within horizontal crevice framed between 2 boulders on Ord Mt $\left(34^{\circ} 40^{\prime} \mathrm{N}, 116^{\circ} 47^{\prime} \mathrm{E}\right)$ Lucerne Valley, California at alt ca $1219 \mathrm{~m}$. Coll 1974 by $\mathrm{T}$ Jackson King, Jr.

REFERENCES

Berger, Rainer, Horney, A G, and Libby, W F, 1964, Radiocarbon dating of bone and shell from their organic components: Science, v 144, p 999-1001.

Heizer, R F, 1964, The western coast of North America, in: Jennings, J D and Norbeck, E, (eds), Prehistoric man in the new world, p 117-148, Chicago, Univ Chicago Press.

Libby, W F, 1955, Radiocarbon dating, 2nd ed: Chicago, Univ Chicago Press, ix, 175 p

Payen, L A, 1970, A spearthrower (Atlatl) from Potter Creek Cave, Shasta County, California, in: Papers on California and Great Basin prehistory, Center for Archaeol Research, Univ California, Davis, pub 2, p 155-170.

Putnam, F W, 1906, Evidence of the work of man on objects from Quaternary caves in California: Am Anthropologist, v 8, p 229-235.

Riddell, F A, 1974, A dated burial from Honey Lake Valley, California: paper read at Great Basin Anthropol Conf, Sept 14, 1974, Carson City, Nevada.

Sinclair, W J, 1904, The exploration of Potter Creek Cave: Univ California, pubs in Am Archaeol \& Ethnol, v 2, p 1-27.

Taylor, R E, 1974, University of California, Riverside radiocarbon dates I: Radiocarbon, v 16, p 395-401.

Treganza A E 1952, Archacological investigations in the Farmington reservoir area, Stanislaus County, California: Univ California Archaeol Survey rept 14, Berkeley.

Treganza, A E and Heizer, R F, 1955, Additional data on the Farmington complex: Univ California Archaeol Survey rept 22, p 28-38. 